\title{
Da friheden kom til K.B. Hallen
}

Don Redman-koncerten 1946

I 1944 blev K.B. Hallen i København bombet af Schalburg-folk. Lige som Tivolis Glassal, der også blev ødelagt, havde den været et symbol på ungdommens kulturelle protest mod nazismen. Her havde jazzen og swingpjatteriet udfoldet sig til besættelsesmagtens og dens danske medløberes store irritation. Aktionen mod de to vigtigste jazzpalæer var således velbegrundet, men ikke psykologisk klog; schalburgtagen bremsede ikke jazzbegejstringen, men gav tværtimod jazzen øget symbolsk værdi som kulturel modstandsform. En modstand, der åbenbart var mere utålelig end de første besættelsesårs alsang og algang.

To år efter, d. 15. september 1946, var K.B. Hallen atter i brug og dannede ramme om den første koncert med amerikanske jazzmusikere i Danmark efter krigen. Duke Ellingtons orkester havde været her i 39 - i de følgende seks år måtte vi klare os med egne talenter (den såkaldte guldalder for dansk jazz).

$\mathrm{Nu}$ åbnedes de kulturelle kommunikationskanaler til - men især fra - USA igen. Det orkester, der genåbnede dem, lededes af Don Redman. En del af koncerten blev optaget privat på 78-plader, som først nu, i 1983, er blevet offentliggjort på to LP'er.

Det er på mange måder en bevægende oplevelse idag at kunne komme til stede ved denne koncert. Oplevelsen er dobbelt, både umiddelbar og reflekteret. Det er muligt at lade sig rive med af denne musik og af de 4000 ekstatiske tilhørere, der oplevede mødet med "disse næsten mytiske skabninger fra en anden verden - rigtige levende amerikanske sorte jazzmusikere", som Dan Morgenstern genkalder sig det i albumnoterne. Og samtidig reflektere over begivenhederne i et "efter"-perspektiv.

Koncerten havde kulturel og symbolsk betydning for dem, der var til stede. For yngre, der hører den på 37 års afstand, er det desuden muligt at fornemme noget andet. For at sige det kort: Jeg har for første gang forstået sanseligt, og ikke bare abstrakt, hvordan det 
egentlig kan være, at så store dele af "forældregenerationen" stædigt er forblevet loyale over for - ja forelskede i - USA gennem alle efterkrigsårene, trods Vietnam, Watergate og alt det andet.

Loyalitetsfølelser og forelskelser skabes ad mange mærkelige kanaler, og et fænomen som pro-amerikanismen har naturligvis utallige årsager. Imidlertid er nogle af dem, der altid nævnes, nok overvurderede, mens andre og mere vitale negligeres.

Hvordan kom de nu 50-60-årige til at elske USA? Sejren over Nazi-Tyskland? Jamen, den førte ikke til samme kærlighed til Sovjetunionen. Marshall-hjælpen? Hjælp takker man højst for, den kommer man ikke til at elske af. Koldkrigen? De følelser, den skabte, var had og frygt og måske beskyttelsestrang, ikke hengivelse.

Der mangler kort sagt noget, som kan forklare, at USA ikke blot betragtedes med respekt eller som det mindst ringe alternativ, men med kærlighed. Den kan næppe søges noget bedre sted end i den slags sanselige møder med amerikansk kultur, som Redman-koncerten var (eller koncerterne, for orkestret optrådte desuden seks steder rundtom i provinsen). En koncert, en film, en modereportage, en roman giver stof til mere engagerende oplevelser end en avismeddelelse om, at Marshall-hjælpen udvides med millioner af dollars.

Redman-koncerten var selvsagt kun én ud af utallige kulturelle påvirkninger i de første efterkrigsår, og man kan mene, jeg overdimensionerer dens betydning. Den er da også kun ét eksempel af mange tænkelige, men dog ét med betydelig vægt.

For det første var symbolværdien ekstremt fortættet. Opstanden af ruinerne genlyder K.B. Hallen atter af en fri verdens fri musik, endda er musikerne fortrinsvis sorte. Alt markerer et endeligt opgør med besættelsesmagtens ideologi, og det har hver eneste af de 4000 tilhørere vidst og følt meget intenst. At koncerten var det første udenlandske besøg betød desuden, at musikerne blev oplevet - ikke som 15 enkeltpersoner, men som repræsentanter for en nation. Og netop én nation, USA; sondringer mellem det "første" og det "andet" USA hører en meget senere tid til. Når Svend Asmussen under krigen lod protestens toner lyde, sang han gerne på et bredt drævende Texas-amerikansk, som for os ville give associationer til "Dallas", J.R. og olie-kapitalisme, men som dengang simpelthen suggererede det amerikanske frihedsrige.

For det andet var det unge publikum - de fleste mellem 15 og 25, siger mine kilder - pakket med personer, der i de følgende årtier blev toneangivende forskellige steder $i$ samfundet. Opinionsdannere, altsả. Mange midaldrende, jeg har talt med $\mathrm{i}$ årenes løb, har 
refereret til Redman-koncerterne som deres største oplevelser fra den tid.

Pudsigt nok har danske jazz-skribenter haft en tendens til at undervurdere koncerterne. Det er sket ud fra en avantgardeorienteret holdning. Redman-orkestret affærdiges som et halvhjertet forsøg på at spille den ny musik, og i stedet fremhæves de halvandet år senere koncerter med Dizzy Gillespies big band, hvor københavnerne for første gang hørte renlivet bop-musik.

Ud fra en snævert æstetisk betragtning kan dette være meget rigtigt, men Redman-koncerternes betydning lå også $\mathrm{i}$ andet end det æstetiske. Forresten forekom musikken nybrydende nok. De, der var til stede, fortæller om dens frygtindgydende uforståelighed. Efter seks år med dansk guldalderjazz i ørerne var det noget af et chok at høre orkestrets hovedsolist, tenorsaxofonisten Don Byas. Selv trænede musikere kunne ikke finde ud af hans harmoniskift, eller om han overhovedet respekterede korinddelingen. På mange års afstand kan man nøgterne fastslå, at han ikke engang var en af orkestrets mest moderne musikere, men stod solidt plantet i traditionen fra Coleman Hawkins (dennes modulationer dog afleveret $\mathrm{i}$ et hidtil uhørt rasende tempo). Men for danskere anno 1946, som ikke havde hørt om Charlie Parkers væsentligt vanskeligere musik hjemme i USA, var Byas rigeligt avanceret.

Andre spillede til gengæld en musik, man genkendte fra 30 'rne. I hvert fald hørt med nutidige øren er det påfaldende, hvor forskelligartede stilretninger der var samlet i dette orkester (der var sammensat ad hoc, med henblik på en Europa-tourné), og hvor uens også arrangementerne var. For mig er denne spændvidde noget af det mest interessante ved orkestret - ud fra en musikalsk, men også en kulturel og social synsvinkel. Hvad der givetvis oplevedes som 15 samspillende repræsentanter for ét Amerika viser sig nu at være et sammensurium af musikalske holdninger $\mathrm{i}$ indbyrdes konflikt, en konflikt som i sidste instans viser tilbage til et generations-, race- og dannelsesmæssigt splittet samfund. Pointeret sagt: den musikalske substans torpederede myten om de tilrejsende ambassadører fra én, fri verden - eller ville have gjort det, hvis publikum havde indstillet sig på at være mytekritisk og i øvrigt besad den fornødne baggrundsviden.

Spændingerne viste sig allerede i musikernes sceneoptræden. Orkesterleder Redman selv havde haft sin store tid i 20'rne og var siden trådt noget i baggrunden. Den attitude, han indtog, var endnu præget af svundne tiders "Uncle Tom"-traditioner: entertainer- 
negeren der fjoller foran et hvidt publikum. Han var kloumen i foretagendet og imødekom således godt indarbejdede publikumsforventninger, f.eks. i sit solonummer ved klaveret, "Dark Glasses". Den lille, korpulente og halvskaldede mand med gaminansigtet spillede på sit udseende, som man huskede Armstrong havde gjort det i 30'rne og Leo Mathisen under besættelsen.

Klovnen var den ene hævdvundne jzzmusiker-attitude. Den anden var elegantieren, som Svend Asmussen, Kjeld Bonfils og Peter Rasmussen havde holdt $\mathrm{i}$ live gennem krigsårene. I Redman-orkestret varetoges den især af den ganske unge pianist Billy Taylor, der brillerede i semi-symfonisk stil med lange perlende løb og pynteklud i jakkelommen.

Klovnen og elegantieren er begge figurér fra varietéen og fra den tribuneoptræden, der i Amerika kaldes vaudevillen. Endnu fjernere aner er tandemparret Dummepeter og Den hvide klovn i cirkus. Jazzhistorisk er de reminiscenser fra en periode, hvor musikken var tæt associeret med gøgl, og hvor sorte musikere måtte rulle med $ø j n e n e$ og gøre badutspring for at tækkes et hvidt publikum.

Der var imidlertid musikere i Redman-orkestret, der indtog en ny og mere selvhævdende positur. Først og fremmest den allerede omtalte Don Byas. Når han spillede en ballade som "Laura" - der for mig, men det er måske en meget privat reaktion, udløser forestillinger om 40'rnes film noir, om Bogart-spleen og storbyisolation så var han ikke entertaineren-foran-publikum, men Mennesket der udtrykker sig selv. Byas var på højde med unge, veluddannede og selvbevidste sort i USA, endnu ikke publikumsforagtende, og endnu ikke omvendt racist, men insisterende på, at negeren er andet end Uncle Tom, ligeværdig med de hvide $\mathrm{i}$ erfaringen af menneskelige grundvilkår.

I musikken gjorde de samme divergenser sig gældende, plus endnu nogle. Redman, der 20 år tidligere havde været en betydeligt komponist og arrangør, gentog gamle succes'er som "Chant of The Weeds". Han viste, at han stadig havde format til at lede et orkester, og at han kunne arrangere nogle ferme og iørefaldende figurer bag solospillet, f.eks. i en forrygende "I got Rhythm". Helt anderledes problematiske var hans forsøg på at være ny med de nye, især $i$ et helt ufrivilligt komisk og overarrangeret nummer, "Frantic Atlantic", som med sine hektiske trompeter, umotiverede temposkift og meningsløse dissonanser kan forekomme som en parodi på Stan Kentons og Pete Rugolos nogenlunde samtidige "progressive jazz".

Tidens moderate hovedstrøm var repræesenteret af flere musikere, 
der enten havde spillet - kortvarigt - med Duke Ellington (saxofonisterne Pete Clarke og Chauncey Haughton) eller senere skulle komme til det (basunisterne Quintin Jackson og Tyree Glenn, den sidste også vibrafonist). Af disse var kun Glenn en markant solist, men denne midtergruppe havde den vigtige funktion at holde sammen på tropperne, forhindre mangfoldigheden $\mathrm{i}$ at blive til kaos. Til de moderate hørte desuden tenorsaxofonisten Ray Abrams, en bred og jordnær solist, der effektivt afbalancerede den flyvske Byas.

Af egentlige modernister var der kun to, som hverken var eller blev særlig kendte, basunisten Jackie Carman og trompetisten Alan Jeffries. Det var tidstypisk for midt-40'rnes opbrud i jazzen, at et stort orkester også rummede bop-folk, og for så vidt blev en almindeligt herskende stilsammenblanding i USA på den tid loyalt afspejlet i Redman-musikernes sammensætning. Det var derimod en utypisk tilfældighed, at de to modernister samtidig var orkestrets eneste hvide medlemmer.

Denne tilfældighed kom til at forplumre begreberne og for en tid udskyde debatten om gammeldags vs. moderne jazz herhjemme. For når de to "blegansigter" - som de omgående døbtes - spillede mystisk og usammenhængende, var det nærliggende at slutte: det er fordi, de er hvide! De nye bop-akkorder - som rigtignok blev noget mekanisk afleveret af især Jeffries - blev opfattet som en racemæssigt begrundet mangel på ægte jazzfølelse. Således erindrer Boris Rabinowitsch det i sine albumkommentarer.

Først med Gillespie-orkestrets optræeden herhjemme halvandet år senere gik det op for et bredere jazzpublikum, at de skæve harmonier og rytmiske friheder ikke var kiksere, men en ny stil - og i høj grad båret frem af sorte. Først da kunne en kvalificeret uenighed opstå i det hidtil sluttede jazzpublikum, med polariseringen i traditionalister og avantgardister til følge.

Havde orkestrets bop-disciple været sorte, eller blot mere talentfulde end Carman og Jeffries, var uenigheden opstået tidligere. I 1946 var det kun en lillebitte håndfuld jazzfans - som Rabinowitsch - der gennem de to hvides musik kunne ane, at noget nyt var undervejs.

Måske kunne de også ane det gennem et par af orkesterarrangementerne. Ikke Redmans egne, der som næunt kun havde en kosmetisk lighed med 40'rnes hvide avantgarde-jazz, men derimod i Tadd Damerons "For Europeans Only" og i "Oo-Ba-Ba-Le-Ba". Dette sidste nummer indledtes med en ensemblepræsentation af Charlie Parkers "Anthropology" og dermed med nogle sekunders 
agte bop.

At "Oo-Ba-Ba-Le-Ba" væeltede huset og blev taget da capo, skyldtes nu ikke dets bop-kvaliteter, tværtimod. Nummeret udviklede sig nemlig hurtigt til et stykke uforfalsket rhythm and blues, med råt trompetspil og vrøvlesang af Peanuts Holland. Dermed viste endnu en tendens sig i denne meget sammensatte koncert. Rhythm and blues blev i 40'rne en art sort populærmusik med en lavere social forankring end den "rigtige" jazz. Dens udøvere og publikum vendte sig imod såvel den efterhånden mere og mere polerede swing musik som mod den komplicerede bop.

Populære "understrømme" havde eksisteret tidligere $\mathrm{i}$ jazzen, f.eks. jump-musikken, der herhjemme var blevet dyrket af brødrene Campbell. Men vi havde ikke tidligere hørt rhythm and blues - en musikform der i det efterfølgende årti udviklede sig til rock'n'-roll.

Hvad disse 15 ambassadører havde at meddele et dansk publikum i disse septemberdage året efter befrielsen var således mangfoldigt indtil det selvmodsigende. I koncertens sluttede form opridsedes et stykke sort amerikansk kulturhistorie præget af brud og kontraster, som alle på en eller anden vis havde at gøre med negrenes forvalt ning af deres situation som undertrykte.

Koncerten var en "tone-parallel til den amerikanske neger", men i en helt anden forstand end Ellingtons store værk "Black, Brown and Beige". Ellingtons musik er en udviklingshistorie, den re-præsenterer flere faser i de farvedes kulturelle tilværelse, men den gør det på en måde, så man som lytter aldrig er i tvivl om, hvad der er retrospektivt, og hvad der er aktuelt. Det historisk tilbagelagte fremstilles som just dét - at de gamle "work songs" med videre stadig forekommer kunstnerisk gyldige er en anden sag, de er udtrykkeligt indplaceret $\mathrm{i}$ et historisk perspektiv. Ellington ser tilbage på en mangfoldig fortid, men punktet, der ses fra, er året 1943. Den konception, der bærer værket, er aktuel. Fortiden levendegøres gennem de musikalske teknikker, Ellington var nået frem til at disponere over i 40'rne.

Redman-orkestret re-præsenterede ikke, men var, en tone-parallel til den amerikanske neger. Det eneste værk, der udtrykkeligt havde repræsentativ karakter, var en spiritual, foredraget af sangerinden Inez Cavanaugh. De roller, musikerne $\mathrm{i}$ øvrigt indtog, var kun i triviel forstand betinget af deres respektive funktioner $\mathrm{i}$ orkestret. Langt vigtigere er det, at de udtrykte forskellige generationers og lags sociale erfaringer $\mathrm{i}$ kunstnerisk formidling.

Negeren, der identificerer sig med aggressor og spiller klovn. 
Negeren, der gør sig salonfähig som elegantier. Negeren, der vil nedbryde racebarrieren ved at svinge sig op i troubadurens almenmenneskelighed. Negeren, der - i protest mod de foregående rolle identificerer sig med storbyghettoens sorte. Og endelig negeren, der vælger avantgardismen som revolteform. Alle disse måder at håndtere undertrykkelseserfaringer på kom til udtryk i Redman-orkestret. At den sidste "neger". tilfældigvis var to hvide forhindrer koncerten i at være ren anskuelsesundervisning i sort kultur fra The Minstrel Shows til Charlie Parker eller Chuck Berry. Men i øvrigt var der også et socialt perspektiv i denne "afvigelse": Jeffries, iført moderigtige solbriller, var vores første møde med den hvide beatnik, der gjorde op med sin middelklassebaggrund ved at tilegne sig sort livsstil og kultur.

Hvad hørte K.B. Hallens 4000 tilhørere nu af alt dette? Receptionsforskning er et dyrt ord for noget, der i realiteten er gætteri, men gættene kan være mere eller mindre kvalificerede. Mon ikke de har hørt en sprudlende vital musik, vanskeligere og mere engagerende end de foregående fem års danske guldalderjazz? Mon ikke de har hørt de stilmæssige divergenser som showprægede afvekslinger og dermed basta? Mon ikke de har set nok så meget som hørt, indsuget oplevelsen af disse 15 smilende og grinende amerikanere, stadset ud efter koder, der endnu var europæerne ubekendte og derfor særlig fascinerende? Og mon ikke konkrete sanseindtryk og politisk-kulturel symbolværdi (sorte i det schalburgterede jazztempel) gensidigt har forstærket hinanden, således at man grangiveligt følte, man havde været i selskab med selve Friheden?

Dette gæt kan underbygges psykologisk. Når man for første gang møder mennesker fra en fremmed verden, vil man for det første hæfte sig ved det, der er fælles for dem, for det andet tolke det som repræsentativt for denne verden. Mødet med det ukendte befordrer syntesearbejde, ikke sønderdeling, analyse. I dette tilfælde var sønderdelingen yderligere besværliggjort af, at de færreste danskere kunne have nogen viden om detaljer $i$ de amerikanske negeres undertrykkelseshistorie - og dermed en referenceramme til tolkning af dens varierede kulturelle udtryk.

Overhovedet at forbinde jazz med USA, og således foretage den mest elementære forankring af musikken, var endnu noget relativt nyt. Som Erik Wiedemann dokumenterer det i "Jazz i Danmark", havde jazzen i lange tider været associeret med urskovshyl, aber etc. - altså med en helt anden verdensdel. Det var dog nok kun fanatiske jazzhadere, der var så galt afmarcheret i 1946. 
Det, de 4000 hørte og så, tjente til at bestyrke og konkretisere kærligheden til Amerika. Det, de måtte overhøre og overse, var, at denne musik i nok så høj grad handlede om undertrykkelsen i dette samfund - og hele fem måder at håndtere den på.

Kærligheden har sikkert været iblandet en følelse af taknemmelighed til disse 15 musikere, der var rejst fra friheden på visit i det hærgede Europa. Det kunne i de følgende år give stof til eftertanke, at flere at Redman-musikerne bosatte sig i Europa. Åbenbart følte de sig bedre tilpas her end i USA. Inez Cavanaugh, Peanuts Holland og Don Byas var blandt de ambassadører, der hoppede af, og efterhånden medvirkede til at give europæere et mindre eksotisk begreb om USA og dets sorte befolkning.

Når jeg har valgt Redman-koncerten som et "værk", der har betydet meget for mig, er det fordi, den har givet mig oplevelse og erkendelse på flere planer - og fordi den herigennem har givet mig større indsigt i, hvad "en stor oplevelse" (for mig) overhovedet består af.

Da Carl Nielsen engang skulle indstudere et af sine nye værker, og en sur orkestermusiker spurgte ham, om det virkelig skulle være smukt, svarede Nielsen: Ikke smukt, men karakteristisk! Min egen omgang med "store oplevelser" betegnes meget godt med Nielsens ord. Jeg søger karakteristiske, blandede fornøjelser.

Værket er i dette tilfælde ikke en koncert, men en pladedokumentation udgivet med 37 års forsinkelse. Dette indebærer et kompliceret spil mellem bevidsthedshorisonter og historiske perioder.

Der er for det første det spil, der holdes gående inden for selve orkestret, hvis historiske arkæologi jeg har søgt at blotlægge. Her skal kun tilføjes, at det klingende resultat af disse modsatninger ikke er polyfon forvirring, orkestret spiller skam "præcist" nok. Overhovedet opfattes konflikterne ikke som æstetiske brist, men som en fylde af vidtforskellige erfaringer. Stilsammenstødene giver dette - som ethvert godt big band - eksistensberettigelse,hvorimod orkestre, der fungerer som "én stor organisme", for mig er uden interesse. Er musikerne blot lydmæssige amplifikationer af hinanden, som i vore dages Count Basie-orkester, er det store orkester blot en decibel-mæssig overskridelse af det lille. Den slags klares lige så effektivt gennem elektrisk forstærkning.

Arene lige omkring krigsafslutningen er i dette perspektiv særlig spændende, for her gik en tradition (fra swingtiden) i opløsning, uden at det nye endnu rigtigt tegnede sig. I dette interregnum var uforudsigeligheden større end både før og efter, konventionsløs- 
heden gav rum for det personlige musikalske udtryk som også i Woody Hermans og Claude Thornhills orkestre på dette tidspunkt. $\mathrm{Da}$ big band'et fandt sin modernistiske form (med Dizzy Gillespie), blev det kedeligere.

For det andet er der spillet mellem orkester og publikum, et historisk betydningsladet møde. Alene af den grund er det bevægende at gen-opleve; for det, jeg i $1983 \mathrm{kan}$ høre og fornemme, er jo ikke blot, at publikum til dels gik fejl af musikken, at pro-amerikanismen foldede sig ud på objektivt set mærkelige præmisser - eller anden "fejlfinding" af ideologikritisk karakter. Jeg genoplever mindst lige så stærkt noget, der ligger over eller under mytedannelserne: efterkrigsdanskernes konfrontation med en både kropslig og intellektuelt stimulerende kunst. At der blandt de tilstedeværende $\mathrm{i}$ salen var mennesker, jeg kender og holder af, beriger denne oplevelse. Og igen er oplevelsen hverken rent følelsesmæssig eller intellektuel, men inklusiv. Jeg deltager i deres glæde, men er samtidig en lurer, der har skaffet sig adgang til intime oplevelser i deres ungdom. Og tager igen bestik af dem.

Endelig er der, for det tredje, forholdet mellem musikken og nutidslytteren. Det er også speget, for musikken er mere karakteristisk end smuk, hvad der efter Carl Nielsens og min mening er i orden. Den er sociologisk karakteristisk, karakteristisk for forvirringen anno 1946, etc. Noget af den lyder gudsjammerligt naiv i $\mathrm{dag}$, men det ville være hykleri at påstå, at disse camp-elementer gør lytteglæden mindre, selv om glæde over det mislykkede eller monstrøse nærmer sig hoveren.

Et enkelt nummer fryder jeg mig ubetinget over, nemlig Don Byas' fortolkning af "Laura", som er mageløst smuk, på én gang statuarisk og rigt forsiret. Men igen er jeg tilbøjelig til at give de amerikanske nykritikere ret, der hævder, at den store oplevelse ikke er den rene, men den inklusive, dvs. den der forener tilsyneladende uforenelige elementer. For "Laura" er i min bevidsthed ikke blot Byas-fortolkningen, men også masser af sentimentale skønsangerversioner - og sågar Spike Jones' grusomme parodi med sirener og snorkelyde. Oplevelsens inklusivitet består således $\mathrm{i}$, at disse forskellige udgaver melder sig $\mathrm{i}$ bevidstheden og dermed travesterer Byas' smukke spil, hvad der ikke gør oplevelsen mindre, men mere interessant og - karakteristisk.

Derfor er mit bud på en stor kunstoplevelse denne Redmankoncert. Den er i enestående grad inklusiv, udfordrende og bevægende, tiltrækkende og frastødende, historiepejlende og -forfalsken- 
de.

Jeg kunne have skrevet om mange andre værker med et mindre skizofrent indhold og en mindre splittet appel. Redman-koncerten tydeliggør imidlertid på en meget udæskende måde noget væsentligt ved min (tør jeg skrive vores?) omgang med kunstneriske oplevelser.

Det gør den ikke blot ved at være live performance, et åbent og kollektivt frembragt kunstværk. Den form garanterer hverken kompleksitet eller bevægelighed, hvad den dystre tomgang og emotionelle smalsporethed $\mathrm{i}$ den såkaldte "jazz-rock". viser.

Den kunst, der interesserer mig, kan være individuelt eller kollektivt skabt, improviseret eller nedskrevet. Intet af dette er afgørende skel. Ubetinget vigtigt er det derimod, at den er mangesporet og omskiftelig, at den rummer bevidsthedssammenstød og historiske spændinger. Den blokerer for glanende hensynken i én følelse, idet den lægger op til såvel indlevelse som distance, bevægelse som ironi og refleksion. Den har ufriheden som sit hovedproblem, men er også munter.

Nykritikkens inklusivitetsbegreb, som jeg allerede har anvendt, peger på nogle af de dobbeltoplevelser, der for mig gør kunst værd at beskæftige sig med. Det sætter dog samtidig nogle normative skranker for, hvor polariseret kunstmeddelelsen må være, og det fordrer, i sidste instans, en enhed i kompleksiteten, der ikke for mig er nogen nødvendighed.

Derfor Redman-koncerten som grelt eksempel. De mange spændinger på kryds og tværs mellem musikere, publikum og nutidige tilhørere harmoniseres jo aldrig. Erfaringsområderne forbliver adskilte, hvad der er i orden for mig, blot det - som her - er tilstrækkeligt vægtige erfaringer, der fremlægges på en måde, der gør det muligt at gribes af dem, reflektere over dem, distancere sig fra dem.

Denne mangesporede, springske, loyalt-illoyale oplevemåde er utvivlsomt historisk bestemt. At udnævne den til selve den moderne historiske sensibilitet ville dog være at tage munden for fuld. Jeg tror ikke, at de inklusive oplevelser dominerer nutidens kulturforbrug, det gør derimod en vis menighedsholdning, udbredt både $\mathrm{i}$ lav-og mellemkulturen. Man finder, hvad man søger i selskab med Erik Paaske og ABBA. Men også sammen med Sebastian og C.V. Jørgensen.

Den udfordrende - sammensatte - oplevelse har jammerlige vilkår i 70'ernes og 80'ernes forskellige musikkulturer (for nu at blive i dette medium). Forholdene kalder på kritik; det, som Adorno kaldte en "hørensregression", og som bl.a. indebærer en angst for at 
gøre musikalske erfaringer, der udfordrer ens selv- og omverdensforståelse, er ikke blot usvækket i populærmusikken, men også i den såkaldt rytmiske musik, der dyrkes af et "progressivt" publikum.

Kritikken er stort set udeblevet. Måske fordi potentielle kritikere har været rædde for at blive slået i hartkorn med 60'ernes kulturradikale og få påduttet den opfattelse, at kulturprodukter er den væsentligste årsag til fremmedgørelse. Og måske - for den rytmiske musiks vedkommende - fordi det medfører en række uoverskuelige tvetydigheder at kritisere den musikalske regression $\mathrm{i}$ den angiveligt politisk progressive tendens.

Disse afsluttende bemærkninger fremsættes ikke for at bringe mig selv i salveten. Jeg står ved mine oplevelser, men bilder mig ikke ind, at de er hævet over kulturelle fejltagelser og fordomme. De er nok repræsentative for en gruppe professionelle kulturarbejdere, der er gamle nok til at have samlet sig en mængde kunstneriske og historiske referencer, og for gamle til at lade sig henrive af usammensatte følelser.

Men hør nu selv Redman-pladerne, selv om du ikke tilhører denne gruppe, og bliv - i hvert fald - en karakteristisk oplevelse rigere.

\section{Referencer}

For Europeans Only. Don Redman and His Orchestra. Recorded Live in Concert. K.B.Hallen, Copenhagen, September 15, 1946. To LP'er udgivet af SteepleChase (SCC-6020/21). Kbh. 1983.

Optagelsen er ikke teknisk pletfri. Trommerne høres f.eks. meget dårligt, af den grund har jeg afholdt mig fra at referere til Buford Oliver, orkestrets efter sigende meget farverige trommeslager.

Erik Wiedemann: Jazz i Danmark I-III. Gyldendal. Kbh. 1982. 